\title{
COVID 19 Nation Lockdown - An Opportunistic Push for Private Label Brands Under Essentials Category
}

\author{
Shailesh.G, Associate Professor, T. John Institute of Management and Science, Bangalore, India \\ shailesh.choudary@gmail.com \\ Priya Vaz, Assistant Professor, PES University, Bangalore, India \\ priyavazreb@pes.edu
}

\begin{abstract}
Due to current COVID-19 pandemic situation across the globe, various sectors have been experiencing tremendous changes in their market responses in both National and International markets. The result of restrictions laid down on Online retailing on one side and controlled operations of supply chain on the other side, have led to changes in business models across sectors. This gave rise to an opportunity for retailers to push their private label brands and fill the gaps in supply chain. This paper emphasizes on the impact of lockdown on consumer buying behavior with respect to essentials category of products.
\end{abstract}

Keywords - COVID-19, Private Label Brands, Essentials, Online Supply chain, Consumer Buying Behavior

\section{INTRODUCTION}

Competition among Private label and National brands in essentials category is increasing gradually due to various changes in the market scenario. Improved quality of private label products, development of premium private label brands, emergence of new channels and creation of new categories were some of the reasons for increasing demand for private label brands. Apart from these, the current COVID-19 pandemic situation driven nationwide lockdown has laid an impact on manufacturing, supply chain activities, marketing and various other business activities. This led to creation of hurdles for national brands supply and business opportunity for private label brands' manufacturers. Private label brands have witnessed encouraging growth. Almost all the Private labels essentials categories ranging from - pulses, flours, rice, oil, hand wash, sanitizer, and cleaners were supplied at its stores during the lockdown. This paper emphasizes on the changes in consumer buying behavior with respect to essentials category during the COVID-19 lockdown scenario.

\section{LITERATURE REVIEW}

\section{A. Essential Goods}

Making the right products available at the right time, at the right place and at the right price to meet the basic or essential needs of the consumers is the core responsibility of the marketers and it requires being well-managed and regulated by the Government to ensure the wellbeing of the consumers. Many studies have been carried out during various situations domestically and globally. Reference [6] claim that the Open Distribution System of Essential Commodities as a Social Security in Satara District of Maharastra and found that lone $29 \%$ of the individuals are happy with the present public distribution system. Further, their examination has likewise asserted that the PDS has failed to guarantee timely supply of the essential products with great quality and reasonable costs to the deprived segments of the certain territory. The Essential Commodities Act, 1955 emphasizes on regulating the prices of essential commodities, without conceding the quality, instigates its significance and consequently stresses the role of marketers, customers, policy makers, Government on this front. Recently the Government of India has approved amendment to the six-a-and-a-half years old Essential Commodities Act, in order to liberalize food items, including cereals, pulses and onion inorder to change the farm sector and aid increase in farmers' income [11].

\section{B COVID-19}

Coronavirus disease (COVID-19) is an irresistible ailment brought about by a newfound coronavirus. This virus has influenced the ordinary life. The lockdown situation has on one side slowed down the economy and on other sideopened doors for existing and new online retailers. This pandemic keeps on affecting practically all enterprises at an unmatched scale, including shopper markets and retail, which has seen noteworthy interruption in the course of recent months. During the lockdown, the buyers are amassing basic merchandise, for example, vegetables and 
fruits, personal care things, preventive medicinal services and cleanliness items. Further, with expected travel constraints and monetary worries later on, it is foreseen that another ordinary would develop where buyers would hope to purchase a greater amount of essential things for example, household and staple goods, healthcare services; while curtailing extravagance and fashion stock.

\section{Online Supply Chain}

Days ahead, another world situation may become visible, wherein retailers across differing classes cannot depend completely on their offline business much after the lockdowns are canceled. They should unavoidably change in accordance with the online buying practice. This will turn out to be significantly progressively pertinent for classes like food supplies and individual consideration where beforehand the affinity to purchase online was low. As needs be, business would be required to arrange themselves with the GST consistence identified with online business. New partnership models have been observed to allow customers to order products at ease. During this phenomenal time, it is basic for us to keep up a consistent gracefully of our items, which are day-to-day staples in Indian families. It is essential for the offline retailers to leverage technologies to sustain in future [12]. Mintel explore uncovers that 44 percent of buyers have expanded the measure of shopping they do web based after the outbreak. This expansion was higher among more seasoned purchasers with 57 percent of those aged 35-54 expanding their internet shopping, contrasted with 32 percent of those aged 18-34. Those matured 35-54 are likewise bound to have amassed goods (59 percent), contrasted with others. With supply chains affected because of the lockdown, customers are compelled to shop on the web and embrace a moderate methodology as they battle to obtain essentials. Kirana stores have indeed become the pillar basic food item suppliers for the righteousness of being near and dear and guaranteeing the accessibility of essentials. FMCG brands need to guarantee accessibility of items by working together with the correct conveyance accomplices and devise appropriate procedures to even more likely serve and ensure availability of essentials for their buyers during and after the lockdown. Consumers are increasingly requesting regarding item customization, cost and level of service [1]. Reference [2] characterize basic adaptability as the capacity of the supply chain to adjust to major changes in the business condition. In any case, adaptability and versatility come at an extra expense as extra assets, for example, buffer stock and additional capacity, and higher organization cost [8].

\section{Private Label Brands}

Product accessibility has been top of thinking for shoppers as food producers conform to satisfy increasing retail need during the COVID-19 pandemic. Empty racks and limited stockouts have upset brand reliability and created expanded preliminary of both national marked and private label staple. Replacements have been especially high among quick selling staples like meat and protein, dairy, pasta, canned merchandise, solidified nourishments, bread and baked items. Price sensitivity additionally has been a factor. There has been more ability to attempt new private label brands than national brands. One of the reasonable causes is that there is typically a lower value line for private mark, and shoppers have had vulnerability or direct effects on their earnings experiencing the present emergency. Those brands that can remain on rack, that can manage the spikes sought after brought about by COVID-19 and the move from away-from-home to food-at-home, are the ones that will be ready to conceivably fortify their brands after some time. The ones that could not remain in stock have a test that they will look as; ideally, we come out and begin to get to recovery [9]. The five keys to success of private label brands during COVID-19 are prioritize innovation, enhance solutions, educate on benefits, deliver inspiration, and lead e-commerce. Private brands historically have not been well represented online and often get lost in digital formats. However, the current change in consumer buying preferences have given a push to private label brands in the market especially in food and groceries segment. Retailers should leverage private brands into unique recipes that can inspire shoppers at home. Retailers should educate the customers on the quality and continuing innovation of its store brands. Retailers should expand their categories that have gained huge demand during COVID-19. However, at first private mark, brands had a low-valued strategy; retailers put forth attempts for genuine quality upgrades in recent years. Nations in Western Europe like United Kingdom, Switzerland, and Germany where organized retail has solidified nearness, portion of private names is as of now in excess of 30 percent and it is relied upon to go significantly higher [3]. Development of organized retail chain in India has additionally prompted development of private labelled products in India. With the development of organized retail in India, the private labelled brands are likewise expected to develop as experienced in other developed nations. The development of private labelled brands in India presents a fascinating open door for the retailer to comprehend the inspirations of purchasers behind decision of private name brands. Private labels or store brands are developed by retailers as an option to drive customers to their retail outlets [7]. This is noteworthy for brands, particularly advertise pioneers in their classes, since people are subjective misanthropes, implying that we utilize mental alternate ways to direct our decisions and choices. As far as buying behavior, when a daily practice in a specific store or inclination for specific brand is built up, it gets constant and is hard to change. In ordinary occasions, picking up buyers' consideration and moving the needle on key shopper behavior measurements was an exorbitant undertaking and regularly past the spending plans and promoting capacities of numerous little and midtier brands. 
The present condition offers a remarkable open door for these littler organizations to go up against their progressively settled adversaries for presentation, mindshare, item preliminaries, and piece of the pie with another and more extensive base of likely customers. Firms and retailers increase cost of products because of cost, competition, demand, or different incidental reasons. Customers, in any case, might see these cost increments as being "reasonable," in this way influencing their buying behavior. This price fairness recognition might be interceded by the customers' impression of the company's market power. Reference [4] stated that when market power is more, customers treat cost as fair and reasonable and vice versa. In many nations, customers likewise express solid inclinations for private label brands over national brand. For example, in Australia about 80 percent state their inclination for private label brands has expanded since before the episode started, while in China - a nation where international; brands have had a verifiably solid reputation-just 43 percent state they have a more prominent inclination to purchase from these brands.

\section{DISCUSSION}

In the past, the impact of various uncertain situations caused by wars, economic imbalances, technological competitions, regional disputes and pandemic situations have led to tremendous change in lifestyles, spending pattern, investments etc. Even in the current situation of COVID-19, the similar observations are made. Globally, manufacturers, service sector, hospitality sector, retail and many businesses are experiencing the slowdown effect. Simultaneously, even the consumer spending behavior, perceived risk and consumption pattern has changed. Various situations like those that job loses, financial insecurity and health consciousness are responsible for change in buying and consumption pattern. This might have negative impact on many existing businesses on one side, but on the other side as the essentials, buying and consumption will not stop. Essentials such as food and groceries, personal care products and medicinal products will continue to have the demand. However, the challenges created due to lockdown such as supply chain restrictions, business operations time restrictions, employee size restrictions in the manufacturing industries have definitely had an impact on supply. Various brand manufactures across product categories have been experiencing this slowdown situation. These observations have given opportunity to private label brand manufactures to meet the existing supply gap and hence, there was an increase in the availability of private label branded products in the retail outlets especially in FMCG and food \& groceries category. Metro Cash \& Carry India said its private label brands have witnessed "encouraging growth" in the past few weeks and enabled the company to cater to its consumer needs through its "own brands" portfolio. Players such as Flipkart have introduced medical supplies range with the launch hand- sanitisers and masks under the Flipkart SmartBuy brand. Currently, private labels or "owned brands" constitute 40 per cent of Grofer's business and it plans to increase this to 60 per cent in the next six months [10]. Walmart India, which runs Best Price cash \& carry stores. It relied on its MSME suppliers to launch its private label brand called Great Value Hand Rub Aqua swiftly to meet the growing demand for hygiene products. The companies believe this will help plug in gaps that arise due to the supply chain disruptions as well as improve access to products in categories such as staples, hygiene products and packaged food [5]. Even other essential products such as sanitizers, hand wash liquids, masks and thermal scan equipment have gained lot of demand. In the situation of demand-supply imbalances, there is a tendency of customers' switching over to other brands and they do not emphasize on brand. The pandemic situation has given a push to private label brands and if they can gain the confidence of customers, the future is going to be challenging for the national brands. Strategies pertaining to product quality, pricing, positioning, distribution, customer relationship should be formulated ideally to match the already existing fame of national brands. This paper has pooled certain insights on the impact of COVID-19 on the current situation of national brands and private label brands. The future studies can emphasize on empirically studying the acceptance level of private label brands across the markets and product categories as well as the challenges to be considered to formulate suitable business strategies by the private label brand owners.

\section{CONCLUSION}

The current market is dynamic. Consumer preferences keep changing and new products are introduced to meet the heterogeneous market structure. During normal situations, it is easy for the existing brands to work on their business strategies but during uncertain situations like COVID-19, various challenges that are mentioned in the discussion part would put the brand strategists into pressure situation. As the businesses have to continue, sustain and look for bringing out the financials from the slow down situation, the strategists should respond aggressively to match with market scenarios. Since, the current situations have created better opportunities for private label brands and currently the customers are also looking at economical buying, it would be the right time to push the brands and capture the customer base. Overall, the future of various brands is going to be challenging, as there will be changes in market structure globally.

\section{REFERENCES}

[1] Christopher, M. 2016. Logistics \& Supply Chain Management. Harlow: Pearson. 
[2] Christopher, M., and M. Holweg. 2011. "“Supply Chain 2.0': Managing Supply Chains in the Era of Turbulence." International Journal of Physical Distribution \& Logistics Management 41 (1): 63-82

[3] Kumar, N, Steenkamp, J.B.E.M. (2007). Private label strategy-How to meet the store brand challenge, Harvard Business School Press.

[4] Lu Zhi, Bolton Lisa, Ng Sharon, Chen Haipeng (Allan), The Price of Power: How Firm's Market Power Affects Perceived Fairness of Price Increases, Journal of Retailing, 2020; 96 (June (2))

[5] Retailers, e-commerce platforms turn to private label brands to plug gaps in supply chains, Meenakshi Verma Ambwani, New Delhi | www.thehindubusinessline.com, Published on April 17, 2020

[6] Sawant B.S. and Jadhav Rahul J. (2013). Public Distribution System of Essential Commodities as a Social Security (A Study of Satara District Maharashtra), International Journal of Management \& Business Studies, Vol.3, Issue 1, Jan-March 2013, pp.31-33

[7] Singhi, R., \& Kawale, D. (2010). Private brands and store loyalty: An empirical study in Noida. Indian Journal of Marketing, 40(9), 31-41

[8] McKinsey \& Company Survey: Food retail in India during the COVID-19 pandemic, April 14, 2020

[9] Lockdown: retailers witness spike in sale of private labels as supply lines disrupted, the week magazine, April 26,2020

[10] Economictimes.indiatimes.com

[11] Corona.mygov.in

[12] www.exchange4media.com 